\title{
VÁROSI KÖZLEKEDÉS MONITOROZÁSA KÖZÖSSÉGI MÉDIA SEGÍTSÉGÉVEL
}

\section{URBAN TRAFFIC MONITORING BY SOCIAL MEDIA}

\author{
Mezei Miklós ${ }^{1}$, Felde Imre $^{2}$, Pintér Gergö ${ }^{3}$

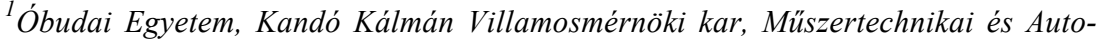 \\ matizálási Intézet, 1084, Magyarország, Budapest, Bécsi út, 96/B; Tel/Fax:+36-20- \\ 2363931,mezei.miklos@kvk.uni-obuda.hu \\ ${ }^{2}$ Óbudai Egyetem, Neumann János Informatikai kar, 1084, Magyarország, Buda- \\ pest, Bécsi út, 96/B; Tel/Fax:+36-1-6665528,felde.imre@nik.uni-obuda.hu \\ ${ }^{3}$ Óbudai Egyetem, Neumann János Informatikai kar, 1084, Magyarország, Buda- \\ pest, Bécsi út, 96/B; Tel/Fax:+36-20-4346956,pinter.gergo@nik.uni-obuda.hu
}

\begin{abstract}
The optimization of urban traffic is still a problem to be solved for high-density areas. Additionally, in our continuously evolving world, punctuality and meeting deadlines have become crucial concepts. Therefore, the time spent on travelling is important information for the population. In order to finetune the traffic, it is helpful to know the destinations, the way the crowd is moving within a given time frame. In this study, data provided through social media was used for the observation of the above mentioned points.
\end{abstract}

Keywords: Traffic, GPS, Facebook, Mobil

\section{Összefoglalás}

A városok közlekedésének optimalizációja a mai napig megoldásra váró problémát jelent a népesen lakott területek számára. Továbbá a folyamatosan fejlődő világunkban a pontosság és a határidők betartás elengedhetetlen. Így az utazási idő, fontos információ a lakosság számára. A közlekedés finomhangolásához nagy segítség, ha tudjuk az utazások célját, a tömegek mozgását, adott időszakra levetítve. A tanulmányban a közösségi média által szolgáltatott adatokat használjuk fel, ezek megfigyelésére.

Kulcsszavak: Közlekedés, GPS, Facebook, Mobil

\section{Bevezetés}

Magyarországon a Facebook és az egyéb Social Media szolgáltatások térhódításával, egyre nagyobb aktivitást figyelhetünk meg az interneten történő felhasználók körében, hisz már mindennapi rutinná vált a Facebook-on és az Instagram-on lévő fényképek és posztok böngészése. A számottevően megnövekedett felhasználói jelenlét következtében érdemes az ott publikusan megosztott adatok vizsgálata. Ezek segítségével, jóval költséghatékonyabban vizsgálhatjuk a városban élö embertömegeket áramlását, mozgását, utazási célját. Ezek megfigyelésére nagyobb városokban, kamera rendszereket, radarokat használnak, ami költséges beruházás és fenntartása egyaránt.

Ebben a tanulmányban föként a publikusan elérhető Social Media által szolgáltatott adatokra koncentrálunk és végzünk következtetéseket. 


\section{Intelligens forgalom irányítási koncepciók}

A városi forgalom irányításhoz már több féle koncepció és megvalósított rendszer is müködik. Ezek a rendszerek magukba foglalják a legújabb kutatások megvalósítását, mint a Dinamikus programozást, ami összetettebb feladatok megoldására alkalmazzák. Kisebb csoportokra bontva (körforgalom, nagyobb csomópontok) megoldva a teljes problémát. A rendszer Fuzzy logikával kombinálva müködik.

Becsléselmélet is segítségre lehet a feladat kivitelezésében. Ahol fóként a Bayes elméletet veszik alapul. Itt a cél a legvalószínűbb és a legkedvezőbb eset meghatározása. Forgalom alakulás szempontjából ez lehet a legfontosabb, hisz érdekes az utazó számára a dugó vagy baleset legvalószínübb kialakulásának helyszíne és a legkedvezőbb útvonal, kiválasztása ennek elkerüléséhez [1-3].

A legkedvezőbb útvonalak megtervezéséhez elengedhetetlen az adatok beszerzése, ami a forgalom jelenlegi állapotáról ad viszszajelzést, továbbá a már meglévő adatokból készít megfelelő statisztikát. Itt többféle adatot vehetünk figyelembe:

- $\quad$ TMC (Traffic Message Channel);

- CDR adat;

- GPS adat;

- Előzőéves forgalmi adatok.

A Smart Navigációk ezekből az adatokból valós időben számítja ki a megfelelő útvonalat. Ezeket az adatokat kiegészíthetjük. A Social media által szolgáltatott adatokkal, így tovább pontosíthatunk az útvonal meghatározásán.

\section{A Social Media által rendelke- zésre álló adatok}

A magyar internetezők a felmérések alapján Facebook, Youtube, Tumbler, Instagram és Foursquare közösségi weboldalakat használják fóként melyeknek a fel- használói száma a következő képen alakul [4]:

- Facebook ( 4,6 millió);

- Youtube ( $\sim 5$ millió);

- Instagram( 300 ezer);

Segítségükkel a felhasználók sok hasznos információt publikálnak, mely információk feldolgozásával hozzájárulhatnak a közösségi forgalom szervezettebb átalakításához. A Facebook segítségével eseményeket hozhatnak létre, ami nyilván rendelkezik egy adott helyszínnel, ahová a felhasználók tartanak, mint úti cél felé vagy már ott vannak. Foursquare-el adott helyre tudnak betaggelni a felhasználók, ehhez időbélyeg is tartozik. Instagram képeihez Geotag rendelhető, ami a kép készültének helyszínt rögzíti. Ez által tudjuk, a felhasználók adott időben hol tartózkodnak vagy épp hol fognak tartózkodni, ami a pillanatnyi útvonal tervezéshez nagy segítséget jelenthet.

\section{A kutatásban során megismert Social Media által szolgáltatott információ felhasználása}

Más nagy országokban elterjedte közösségi szolgáltatás a Twitter, ami sajnos Magyarországon kevésbé használatos. A Twitter segítségével rövid szöveges üzenetet küldhetünk követőink számára, ami persze publikusan is látható, a megfelelö felhasználói beállítás mellett.

A Twitter rendelkezik egy ingyenes elérhető API szerver funkciókkal, melynek segítségével lekérdezhető, hogy honnan és mikor érkezett az adott bejegyzés. Továbbá a bejegyzés tartalma is elérhető. Megfelelöen karbantartott felhasználó fiókkal, például rendőrség által validált felhasználó által megvalósítható, hogy folyamatosan tájékoztatást kaphassanak a felhasználók a forgalom állapotáról. A rendszerhez bárki csatlakozhat, aki szeretne közlekedéshez kapcsolatos információt megosztani, így elkezdve a közösségi közlekedés építését természetesen felügyelve, hisz félrevezető informáci- 
ókkal nem kívánatos problémákat okozhat a rendszerben. A Twitter rendelkezik olyan API hívásokkal, ami segítségével az üzenetek helyét könnyel elérhetjük a fentebb említett módszer segítségével viszont módszeresen járulhatunk hozzá a közlekedés optimalizálásához.

\section{A kutatásról konkrétan}

Magyarországon az adatok összegyüjtését és vizsgálatát Budapesten Államalapítás ünnepén pontosan 2014.08.20-án végeztük. Azért erre a napra esett a választás, mert ekkor a legreprezentatívabb az ember tömegek mozgása és sokkal egyértelmübb az utazási céljaik.

A rendelkezésre álló CDR adatainkat vizsgáltuk a Social Media által szolgáltatott adatokkal. A CDR mobil operátorok által gyüjtött adat, ami adott időpontba meghatározza a felhasználó koordinátához kötött cella helyzetét, aktivitását. A Facebook eseményeit vizsgáltok az adott napra. Sajnos korlátozott a hozzáférés, de így is jelentős információhoz juthatunk. A Facebook Graph API segítségével. Ez egy szerver funkció, mely adott relációkkal enged lekérést folytatni a szerveren. Ez által egyes publikus eseményekhez hozzáférhetünk. Megkaphatjuk az adott eseményre visszaigazolt felhasználók számát és az esemény pontos helyszínét. Ezzel megkaptuk egy adott felhasználó réteg utazási célját, ahová nagy valószínűséggel érkezni fognak.

1. táblázat. Elérhetö publikus események adott idöpontra Facebook alapján

\begin{tabular}{|c|c|}
\hline $\begin{array}{c}\text { Publikus esemény } \\
\text { száma }\end{array}$ & Vissza igazolt \\
\hline $15 \mathrm{db}$ & 6962 fö \\
\hline
\end{tabular}

Két kerületben látványosan kiemelkedő a résztvevők létszám ez a 11 . és az 5 . kerület. A CDR adatink a következő eredményeket hozták.
2. táblázat. $C D R$ adatok által kerületi bontásban

\begin{tabular}{|c|c|}
\hline 5. kerület & 11. került \\
\hline 60397 fö & 5100 fö \\
\hline
\end{tabular}

Megállapíthatjuk, hogy a 11. kerületben majdnem az ott aktív felhasználók az eseményre a Facebook-on meghirdetett eseményre érkeztek. A CDR aktivitások komparálva az esemény létszámával láthatunk számbeli eltérést, ez a publikus események korlátos eléréséből adódhat.

\section{Köszönetnyilvánítás}

Ezúton szeretnék köszönetet mondani az Óbudai Egyetem Robottechnikai Szakkollégium részére, amelynek tagjaként számos szakmai és anyagi támogatást kaptam jelen szakmai tudományos publikációm elvégzéséhez. A szakkollégium kiemelt segítséget nyújt az Óbudai Egyetem tehetséges hallgatóinak és doktoranduszainak.

A tanulmány a TÉT_12_MX-1-20130001 és International $\mathrm{S} \& \mathrm{~T}^{-}$Cooperation Program of China, Granted No. 2014DFG72020 projektek támogatásával valósult meg.

\section{Következtetések}

A CDR és Facebook eseményei által szolgáltatott adatokat összevetve jó közelítéssel megállapíthatjuk, hogy az ember tömegek milyen úti célt is céloztak meg maguknak. Sajnos a Facebook korlátozza a hozzáféréseket egyes eseményeihez, de az elérhetők is hasznos információval szolgálnak. Mivel a CDR adatok egy antenna által lefedett területet jelölnek így csak egy adott zónára érkező emberek figyelhetünk meg. Ezzel szemben a Facebook eseményei pontos címet tartalmaznak, mely segítségével az úti cél is konkretizálódik. Ezáltal már tervezhető az adott terület, útvonal terhelése. Megállapíthatjuk, hogy a Social Meda által szolgáltatott adatok megfelelő feldolgozása, pontosít az adatainkon és további 
felhasználásra ad lehetőséget a forgalom szervezős szempontjából.

\section{Szakirodalmi hivatkozások}

[1] G. V. Lioudakis: An Intelligent Traffic Management System for the EcoOptimization of Urban Traffic Flows. Communications Workshops (ICC), 2010.

[2] T. Gang: Fuzzy Neural Network Model Applied in the Traffic Flow Prediction. Proceedings of the 2006 IEEE International
Conference on Information Acquisition, August 20 - 23, 2006.

[3] J. Zhang: Smarter outlier detection and deeper understandingof large-scale taxi trip records: a case study of NYC. InSIGKDD, '12 Workshop on Urban Computing.

[4] Web:http://analytics.socialdaily.com/hu/face book/countries/HU/,http://newsroom.fb.com/ company-info/, utolsó megtekintés ideje: 2014. 